\title{
URGENSI PENGATURAN CYBER NOTARY DALAM MENDUKUNG KEMUDAHAN BERUSAHA DI INDONESIA
}

(The Urgency of Cyber Notary Regulation in Supporting Ease of Doing Business in Indonesia)

\author{
Muhammad Farid Alwajdi \\ Fakultas Hukum Universitas Ahmad Dahlan \\ Jl. Ringroad Selatan, Kragilan, Tamanan, Banguntapan Bantul, D.I. Yogyakarta. \\ e-mail: muhammad.farid@law.uad.ac.id
}

Naskah diterima: 9 April 2020; revisi: 14 Juli 2020; disetujui: 15 Juli 2020

\begin{abstract}
Abstrak
Doing Business yang diterbitkan oleh Bank Dunia disebutkan ada peran notaris yang mempengaruhi indeks kemudahan berusaha di Indonesia. Peran notaris antara lain dalam hal membuat akta perusahaan. Indeks kemudahan berusaha menilai faktor prosedur dan waktu dalam menentukan skor kemudahan berusaha. Oleh karena itu, semakin cepat dan ringkas prosedur yang diperlukan dalam membuat akta maka semakin naik pula indeks kemudahan berusaha. Penelitian ini mengkaji urgensi pengaturan cyber notary dalam Undang-Undang Jabatan Notaris (UUJN) sehingga akan berpengaruh terhadap indeks kemudahan berusaha di Indonesia. Penelitian ini menggunakan metode yuridis normatif. Hasil penelitian ini menunjukkan bahwa pengaturan cyber notary untuk mendukung kemudahan berusaha adalah dengan merubah Pasal 15 ayat (1) UUJN dan menambahkan kewenangan agar pembacaan akta dan tanda tangan diperbolehkan tanpa tatap muka (online). Dengan cara tersebut maka prosedur pembuatan akta dapat dipotong, sehingga prosesnya kurang dari 1 (satu) hari.
\end{abstract}

Kata Kunci: kemudahan berusaha, cyber notary, akta notaris

\begin{abstract}
Doing Business published by the World Bank, there is a notary role affecting the business ease index in Indonesia. The role of the notary public is to make company deed. Doing Business assesses procedure and time factors in determining the score. Therefore, the faster and more concise the procedure required to make the deed, the more higher the Ease of Doing Business index is. This study examines the urgency of cyber notary arrangements in the Law of Notary Position (UUJN) so that it will affect the ease of doing business index in Indonesia. This research uses normative-legal method. The results of this study indicate that the cyber notary arrangement to support ease of doing business is to amend Article 15 paragraph (1) of the UUJN so that the reading of deeds and signatures is permitted without being face-to-face (online). In this way the procedure for making the deed can be cut, so that the process takes less than 1 (one) day.
\end{abstract}

Keywords: ease of doing business, cyber notary, notarial deed 


\section{A. Pendahuluan}

Konsep cyber notary atau e-notary bagi notaris di Indonesia bukan merupakan sesuatu yang asing, sejak tahun 1995 telah ada wacana untuk mengembangkan konsep cyber notary di Indonesia. ${ }^{1}$ Konsep ini lahir karena adanya teknologi-teknologi baru yang dapat mempengaruhi perkajaan notaris terutama dalam hal efisiensi waktu. Teknologi-teknologi tersebut antara lain tanda tangan digital (digital signature) dan video conference. Kehadiran teknologi-teknologi tersebut tentu merupakan suatu keniscayaan yang tidak dapat disangkal.

Permasalahannya adalah seorang notaris dalam menjalankan jabatannya terikat dengan Undang-Undang Nomor 2 Tahun 2014 tentang Perubahan Atas Undang-Undang Nomor 30 Tahun 2004 tentang Jabatan Notaris (UUJN). Dalam konsideran UUJN disebutkan bahwa fungsi notaris adalah membuat akta autentik untuk menjamin kepastian, ketertiban dan perlindungan hukum. ${ }^{2}$ Mengenai definisi apa yang dimaksud akta autentik tidak disebutkan dalam UUJN, kita dapat merujuk kepada Pasal 1868 Kitab Undang-Undang Hukum Perdata (KUHPerdata). Pasal 1868 KUHPerdata menyebutkan bahwa apa yang dimaksud dengan akta autentik harus memenuhi 3 kriteria yaitu: (1) akta tersebut dibuat harus sesuai dengan bentuk yang ditentukan dalam Undang-Undang; (2) Dibuat oleh pejabat yang berwenang; dan (3) Pejabat tersebut berwenang membuat ditempat kedudukannya.

Ketentuan tersebut bersifat kumulatif artinya ketiga unsur tersebut harus ada dalam unsur akta autentik. Akta autentik sendiri fungsinya sebagai alat bukti yang sempurna. ${ }^{3}$ Pihak lawan yang menyangkal kebenaran dari isi akta tersebut maka dialah yang harus membuktikannya (actori incumbit probatio). Selain menjadi alat bukti yang sempurna, akta notaris juga sering difungsikan sebagai syarat formil dari suatu perjanjian. Artinya perjanjian tersebut supaya mempunyai kekuatan hukum harus memenuhi syarat-syarat tertentu. Seperti pembuatan perjanjian perkawinan, pembuatan akta perseroan terbatas dan akta jaminan fidusia.

Jabatan notaris ini erat kaitannya dengan pelayanan kepada masyarakat, khususnya dalam melayani dunia usaha. Bagi dunia usaha selain membutuhkan jaminan kepastian hukum, juga dibutuhkan kecepatan/ keluwesan. Kecepatan perkembangan dunia usaha ini seringkali tidak berjalan beriringan dengan norma hukum yang kaku yang lebih menekankan pada aspek kepastian hukum.

Paradigma UUJN lebih menekankan kepada kepastian hukum yang berarti norma-norma dalam membuat akta autentik dibuat sedemikian rupa sehingga menjamin pembuktian yang sempurna. Misalnya harus dibacakan dan harus hadir dihadapan notaris untuk tanda tangan akta. ${ }^{4}$ Terbitnya 
laporan Ease Of Doing Business (EODB) atau kemudahan berusaha dari Bank Dunia menjadi petunjuk bahwa dunia usaha menghendaki agar negara-negara mengeluarkan sejumlah kebijakan yang mendukung kemudahan berbisnis. Negara yang indeks kemudahan berusahanya bagus akan dipandang sebagai negara yang ramah investasi. Sebagai catatan Indonesia pada tahun 2019 menduduki peringkat 73 dari sekitar 190 negara yang disurvei.

Beberapa hal yang diukur dalam EOBD adalah: (a) memulai usaha (starting business), (b) mengurus izin pembangunan (dealing with construction permits), (c) instalasi listrik (getting electricity), (d) mendaftarkan tanah (registering property), (e) memperoleh kredit/ pinjaman (getting credit), (f) perlindungan terhadap investor minoritas (protecting minority investor), (g) perdagangan lintas batas (trading across borders), (h) membayar pajak (paying taxes), (i) penegakan hukum kontrak (enforcing contracts), (j) penyelesaian kepailitan (resolving insolvency), (k) mempekerjakan karyawan (employing workers)..$^{5}$ Dari 10 indikator tersebut yang berkaitan langsung dengan fungsi notaris adalah indikator memulai usaha (starting business) yang akan dielaborasi lebih lanjut dalam penelitian.

Ada 3 (tiga) alasan mengapa penerapan cyber notary ini penting bagi negara Indonesia: Alasan Pertama, bahwa pemerintah menargetkan agar Indonesia mendapatkan rangking minimal 40 besar indeks EODB ${ }^{6}$ dan dalam kongres internasional notaris presiden Joko Widodo menyampaikan keinginginannya agar notaris merespon tuntutan zaman tersebut. ${ }^{7}$ Alasan Kedua, bahwa pendirian Perseroan Terbatas (PT) sebagai salah satu indikator yang digunakan dalam menentukan indeks EODB. Notaris sebagai pejabat publik yang diberikan kewenangan oleh negara untuk membuat akta pendirian PT tersebut selain harus paham aturan-aturan yang ada dalam UUJN juga harus paham mengenai perubahanperubahan apa saja yang terjadi dalam proses pembuatan PT. Alasan Ketiga, pada Pasal 22 UUJN dinyatakan bahwa formasi notaris dapat dibuka dengan mempertimbangkan 3 hal: (1) kegiatan dunia usaha, (2) jumlah penduduk, (3) rata-rata jumlah akta yang dibuat notaris tiap bulan.

Tercantumnya indikator "kegiatan dunia usaha" sebagai faktor yang menentukan jumlah kebutuhan notaris di suatu daerah membuktikan bahwa profesi notaris erat kaitannya dengan dunia usaha. Oleh karena itu, Notaris harus mampu merespon perkembangan dunia usaha tersebut dan bagaimana beradaptasi dengan tuntutan zaman yang menghendaki efisiensi waktu dalam proses pembuatan akta. Salah satu cara agar pembuatan suatu akta dapat lebih cepat adalah menerapkan konsep cyber notary dalam UUJN.

5 World Bank Group, "Economy Profile Indonesia: Doing Business 2020", https://www.doingbusiness.org/ content/dam/doingBusiness/country/i/indonesia/IDN.pdf. (diakses 5 Maret 2020).

6 CNBC INDONESIA, "Jokowi Bidik Indonesia Indonesia Bisa Capai Peringkat 40 EODB", https://www. cnbcindonesia.com/news/20200213142449-8-137644/jokowi-bidik-indonesia-bisa-capai-peringkat-40-eodb (diakses 05 Maret 2020).

7 Hukum Online, "Presiden Minta Pola Kerja Notaris Berubah, Begini Tanggapan INI", https://www.hukumonline. com/berita/baca/lt5de0fe8832c1b/presiden-minta-pola-kerja-notaris-berubah--begini-tanggapan-ini/ (diakses 05 Maret 2020). 
Permasalahannya regulasi yang ada saat ini belum menjabarkan seperti apa konsep cyber notary meskipun telah dibuka pengaturannya lewat Pasal 15 ayat (3) UUJN. Hal tersebut berdampak pada cyber notary yang belum dapat dilaksanakan sehingga berpengaruh terhadap indeks kemudahan berusaha. Oleh karena itu, dalam penelitian ini akan dibahas mengenai: (a) bagaimanakah pengaturan cyber notary dalam UUJN saat ini dan (b) bagaimanakah konsep seharusnya cyber notary dalam mendukung kemudahan berusaha di Indonesia.

\section{B. Metode Penelitian}

Penelitian ini merupakan penelitian hukum normatif. Penelitian hukum normatif merupakan penelitian terhadap asas-asas hukum, sistematika hukum, taraf sinkronisasi hukum, sejarah hukum dan perbandingan hukum. ${ }^{8}$ Ciri dari penelitian hukum normatif adalah menggunakan bahan pustaka atau data sekunder, yang terdiri dari bahan hukum primer, sekunder, dan tersier. ${ }^{9}$ Bahan hukum primer merupakan bahan hukum yang pokok dan wajib digunakan dalam melakukan penelitian ini seperti peraturan perundangundangan. ${ }^{10}$ Bahan hukum sekunder adalah bahan yang menjadi petunjuk ke arah mana peneliti melangkah, seperti: jurnal-jurnal hukum. ${ }^{11}$ Bahan hukum tersier adalah bahan hukum yang mendukung bahan hukum primer dan bahan hukum sekunder seperti kamus hukum. Data sekunder diperoleh dari penelitian kepustakaan dengan metode dokumentasi dan alat pengumpulan data berupa studi dokumen. Dari data-data yang diperoleh dari penelitian ini kemudian dianalisis secara deskriptif kualitatif.

\section{Pembahasan}

\section{Konsep Cyber Notary dalam Undang- Undang Jabatan Notaris}

Bagian ini akan membahas 3 (tiga) hal yaitu: (a) apa itu cyber notary?; (b) mengapa perlu cyber notary?; (c) bagaimana konsepsi cyber notary dalam UUJN?. Pertama, cyber berasal dari bahasa inggris yang artinya "maya/tidak nampak". Penggunaan istilah cyber juga telah sering digunakan dalam penegakan hukum misalnya cyber crime atau dalam kegiatan ekonomi dengan istilah cyber economy. Ditinjau dari segi konsep, cyber notary adalah metode/cara bekerja seorang notaris yang memanfaatkan perkembangan teknologi yang ada. ${ }^{12}$ Istilah berbeda namun dengan makna yang sama adalah Electronic Notary (E-Notary $)^{13}$ ataupun Notaris Mayantara ${ }^{14}$. Kedua istilah tersebut sama maknanya dengan cyber notary yang kurang lebih adalah perubahan cara kerja notaris yang konvensional (tatap muka) menuju cara kerja yang modern (tanpa tatap muka) dengan memanfaatkan teknologi yang ada. Edmon

Soerjono Soekanto, Pengantar Penelitian Hukum (Jakarta: UI-Press, 1986), hlm. 51.

Ibid, hlm. 52.

Peter Mahmud Marzuki, Penelitian Hukum (Jakarta: Prenadamedia group, 2019), hlm. 181.

Ibid, hlm. 196.

12 R.A. Emma Nurita dalam Habib Adjie, "Konsep Notaris Mayantara Menghadapi Tantangan Persaingan Global", Jurnal Hukum Respublica, Vol. 16, No. 2 (2017), hlm. 201-218.

13 Leslie G. Smith, The Role of Notary in Secure Electronic Commerce, (Brisbane: Queensland University of Technology, 2006), hlm. 1.

14 Habib Adjie, Op Cit. 
Makarim memaknai cyber notary ini sebagai peran notaris dalam transaksi elektronik dengan cyberspace (ruang siber). ${ }^{15}$ Istilah cyber notary juga dikenalkan oleh American Bar Association yang mengartikan sebagai notaris yang mempunyai kemampuan dalam bidang komputer dan hukum. ${ }^{16}$

Dipilihnya istilah cyber notary dalam penulisan ini karena istilah inilah yang diakomodir dalam hukum positif Indonesia (UUJN). ${ }^{17}$ Konsep cyber notary ini juga erat kaitannya dengan regulasi di bidang penyelenggaraan informasi dan transaksi elektronik. Pemerintah melihat ada peran notaris dalam penyelenggaraan informasi dan transaksi elektronik di Indonesia. Misalnya dalam hal tanda tangan digital (digital signature). Dalam UU Nomor 11 Tahun 2008 tentang Informasi dan Transaksi Elektronik (ITE) disebutkan bahwa tanda tangan elektronik memiliki kekuatan hukum dan akibat hukum yang sah atau sama dengan tanda tangan manual dengan syarat-syarat tertentu. ${ }^{18}$

Penggunaan teknologi informasi oleh notaris dalam melaksanakan pekerjaannya bukanlah hal yang baru. Beberapa pekerjaan yang berhubungan dengan notaris sudah mulai mengalami transisi dari metode konvensional ke arah penggunaan teknologi informasi, seperti: pendaftaran fidusia online, pendaftaran haktanggungan secara elektronik, pendaftaran badan hukum dan badan usaha secara online, kewajiban mengenal beneficial owner terhadap perusahaan yang didirikan, sampai dengan memahami maksud dan tujuan usaha yang didirikannya agar selaras dengan perizinannya melalui online single submission (OSS).

Kedua, mengapa konsep cyber notary ini muncul? Jawaban secara sederhana tentu karena adanya tuntutan zaman. Tuntutan zaman seperti apa? Salah satunya tuntutan yang menginginkan efisiensi waktu dalam bekerja. Penggunaan teknologi ini apabila dihubungkan dengan kewenangan notaris maka tujuannya adalah merubah cara bekerja seorang notaris. Cara bekerja yang yang semakin praktis dan efisien bagi masyarakat yang membutuhkan jasa notaris. Artinya untuk menilai apa yang disebut lebih praktis dan lebih efisien kita harus mengetahui bagaimanakah ketentuan peraturan yang ada sekarang (ius constitutum) dan kebutuhankebutuhan yang dikehendaki oleh masyarakat (ius constituendum).

Secara ius constitutum (UUJN) memberikan kewenangan pokok/utama seorang notaris untuk membuat akta autentik. Para pihak ketika membuat akta notaris tujuan utamanya adalah mendapatkan alat bukti yang autentik. Sudikno Mertokusumo juga menjelaskan bahwa suatu akta dibuat dengan tujuan sebagai alat bukti. ${ }^{19} \mathrm{Hal}$ tersebut diperkuat

15 Edmon Makarim, "Modernisasi Hukum Notaris Masa Depan: Kajian Hukum Terhadap Kemungkinan Cyber Notary di Indonesia", Jurnal Hukum \& Pembangunan, Vol. 41, No. 3 (2011), hlm. 466-499.

16 Laurence Leff (editor), "Notaries and Electronic Notarization", https://www.oasis-open.org/committees/ download.php/4541/enotarization.pdf. (diakses 07 April 2020).

17 Penjelasan Pasal 15 ayat (3) Undang-Undang Nomor 2 Tahun 2014 tentang Perubahan atas Undang-Undang Nomor 30 Tahun 2004 tentang Jabatan Notaris.

18 Pasal 11 ayat 1 Undang-Undang Nomor 11 Tahun 2008 tentang Informasi dan Transaksi Elektronik.

19 Sudikno Mertokusumo dalam Irfan Iryadi, "Kedudukan Akta Otentik dalam Hubungannya dengan Hak Konstitusional Warga Negara", Jurnal Konstitusi, Vol. 15, No. 4 (2018), hlm 796-815. 
dalam konsideran UUJN yang menyatakan bahwa perlu ada jabatan tertentu yang diamanahi untuk membuat alat bukti tertulis yang bersifat autentik. ${ }^{20}$

Dalam UU No. 30/2004 UUJN disebutkan bahwa notaris adalah pejabat umum yang berwenang membuat akta autentik dan kewenangan lainnya sebagaimana dimaksud dalam undang-undang ini. ${ }^{21}$ Dari definisi dalam UU No. 30/2004 UUJN kewenangan notaris tidak hanya membuat akta autentik saja, namun ada "kewenangan lain" yang disebutkan dalam UU a quo. Dalam UU No. 2/2014 UUJN(P) definisi notaris mengalami perubahan yaitu: pejabat umum yang berwenang untuk membuat akta autentik dan memiliki kewenangan lainnya sebagaimana dimaksud dalam undang-undang ini atau berdasarkan undang-undang lainnya. Dari definisi tersebut dapat disimpulkan bahwa tugas seorang notaris selain membuat akta autentik, juga mempunyai kewenangan lain yang ditentukan di dalam UUJN maupun di luar UUJN. Penjabarannya sebagai berikut:

Kewenangan Pertama, kewenangan membuat akta autentik yang merupakan tugas pokok notaris dijelaskan dalam bab tentang kewenangan pada Pasal 15 ayat (1) UUJN: Notaris berwenang membuat akta autentik mengenai semua perbuatan, perjanjian, dan penetapan yang diharuskan oleh peraturan perundang-undangan dan/atau yang dikehendaki oleh yang berkepentingan untuk dinyatakan dalam akta autentik, menjamin kepastian tanggal pembuatan akta, menyimpan akta, memberikan grosse, salinan dan kutipan akta, semuanya itu sepanjang pembuatan akta itu tidak juga ditugaskan atau dikecualikan kepada pejabat lain atau orang lain yang ditetapkan oleh undangundang. Dari Pasal 15 ayat (1) UU a quo disimpulkan bahwa akta autentik yang dibuat oleh notaris itu ada 2 macam: (1) diharuskan oleh peraturan perundang-undangan sebagai syarat formil sahnya suatu hubungan hukum, seperti akta pendirian PT dan akta jaminan fidusia; (2) dikehendaki oleh pihak yang berkepentingan.

Kewenangan Kedua, kewenangan yang ada di dalam UUJN seperti yang termaktub dalam Pasal 15 ayat (2) UU a quo, antara lain: legalisasi, waarmeking, legalisir, copy collationee, memberikan penyuluhan hukum berkaitan dengan akta, membuat akta risalah lelang, dan membuat akta yang berkaitan dengan pertanahan. Kewenangan Ketiga, kewenangan yang ada di luar UUJN sebagaimana disebutkan dalam Pasal 15 ayat (3) UU a quo: notaris mempunyai kewenangan lain selain yang dimaksud dalam Pasal 15 ayat (1) dan ayat (2) yang diatur dalam peraturan perundang-undangan. Ketentuan dalam Pasal 15 ayat (3) UU a quo ini menimbulkan pertanyaan lebih lanjut seperti apakah kewenangan notaris yang diatur dalam peraturan perundang-undangan di luar UUJN akan sesuai dengan ketentuan yang terdapat di dalam UUJN dan apakah akta yang dibuat oleh notaris ketentuan di luar UUJN dapat dikualifikasikan sebagai akta autentik?

Selanjutnya untuk menjawab kebutuhan masyarakat terhadap notaris yang dikehendaki saat ini seperti apa (ius constituendum). Mencermati ketentuan yang terdapat di dalam 
UUJN kita mendapati bahwa tugas pokok notaris adalah melayani masyarakat akan kebutuhan alat bukti tertulis yang autentik. ${ }^{22}$ Pada praktik yang berkembang saat ini, tugas seorang notaris telah bertambah kepada kebutuhan akan syarat formil perjanjian yang diwajibkan oleh peraturan perundangundangan untuk dibuat dengan akta notaris. Contohnya dalam pembuatan akta PT dan akta fidusia, akta yayasan dan akta perkumpulan wajib memakai akta notaris. Kebutuhan untuk memenuhi syarat formil menjadikan akta notaris bukan lagi sekedar anjuran (alat bukti) namun suatu keharusan agar perjanjian dianggap sah. Tanpa syarat formil ini suatu perjanjian dianggap tidak sah di depan hukum.

Profesi notaris juga diharapkan untuk melayani transaksi-transaksi secara elektronik (e-commerce) yang membutuhkan autentisitas akta-akta elektronik. ${ }^{23}$ Profesi notaris cenderung melayani dunia usaha, ${ }^{24}$ bahkan UUJN menyebutkan jumlah formasi (kebutuhan) notaris disuatu daerah ditetapkan berdasarkan kegiatan dari dunia usaha. ${ }^{25}$ Sebagai contoh: Jakarta sebagai ibukota negara yang juga sebagai pusat perekonomian Indonesia ditetapkan sebagai formasi daerah A oleh Permenkumham Nomor 27 tahun 2016 tentang Formasi Jabatan Notaris dan
Penentuan Kategori Daerah. Arti dari suatu daerah yang mendapatkan kategori "daerah A" oleh pemerintah adalah daerah tersebut kegiatan ekonominya lebih maju daripada daerah yang lain (ada 4 kategori daerah: A, B, C dan D).

Pertanyaan selanjutnya bagi dunia usaha adalah akta notaris seperti apa yang dibutuhkan? Bagi dunia usaha tentu selain kebutuhan akan alat bukti autentik juga efisiensi waktu dan kemudahan pada saat proses pembuatan akta autentik tersebut. Terdapat penelitian yang menunjukkan bahwa kecepatan pelayanan pada kantor notaris berpengaruh terhadap indeks kepuasaan pelanggan. $^{26}$ Berbagai pengurusan seperti pendaftaran fidusia online, pendaftaran HT elektronik, pesan nama badan hukum secara online menjadi bukti bahwa dunia usaha menghendaki efisiensi waktu dan kemudahan dalam segala urusan terkait aspek legalitas.

Permasalahannya adalah seorang notaris dalam bekerja harus tunduk kepada UUJN. Seorang notaris yang tidak membuat akta seperti apa yang diperintahkan dalam UUJN maka akta tersebut dapat terdegradasi menjadi akta di bawah tangan. Sebagaimana disebutkan dalam Pasal 41 UUJN: pelanggaran terhadap ketentuan sebagaimana dimaksud dalam Pasal 38, Pasal 39, dan Pasal 40

22 Pendapat serupa disampaikan oleh R.A Emma Nurita dalam Syamsir; Elita Rahmi; dan Yetniwati, "Prospek Cyber Notary Sebagai Media Penyimpanan Pendukung Menuju Profesionalisme Notaris", Recital Review, Vol. 1, No. 2 (2019), hlm. 132-147.

23 Sukarmi, Cyber Law: Kontrak Elektronik dalam Bayang-Bayang Pelaku Usaha, (Bandung: Pustaka Sutra, 2008), hlm. 138.

24 Yetniwati; Elita Rahmi; dan Hartati, "Peran Notaris Dalam Pembuatan Kontrak Bisnis, Pengabdian Masyarakat Pada Fakultas Hukum Universitas Jambi", Jurnal Karya Abdi Masyarakat, Vol. 3, No. 2 (2019), 176-181.

25 Pasal 22 ayat (1) huruf a Undang-Undang Nomor 2 Tahun 2014 tentang Perubahan atas Undang-Undang Nomor 30 Tahun 2004 tentang Jabatan Notaris.

26 Debi Eka Putri; Darwin Lie; Efendi; dan Ady Inrawan, "Pengaruh Kualitas Pelayanan Jasa Terhadap Kepuasaan Pelanggan pada Kantor Notaris dan PPAT Rachmansyah Purba SH Mkn di Kota Pematangsiantar" Jurnal Sultanist, Vol. 2, No. 2 (2014), hlm. 17-23. 
mengakibatkan akta hanya mempunyai kekuatan sebagai akta di bawah tangan. ${ }^{27}$ Pasal 44 ayat (5) bahkan menyebutkan konsekuensi apabila akta notaris menjadi akta di bawah tangan yaitu notaris dapat dimintai pertanggungjawaban secara perdata. Pasal 44 ayat (5) menyebutkan sebagai berikut: pelanggaran terhadap ketentuan Pasal 44 ayat (1), Pasal 44 ayat (2), Pasal 44 ayat (3), dan Pasal 44 ayat (4) mengakibatkan suatu akta hanya mempunyai kekuatan pembuktian sebagai akta di bawah tangan dan dapat menjadi alasan bagi pihak yang menderita kerugian untuk menuntut penggantian biaya, ganti rugi, dan bunga kepada notaris. ${ }^{28}$

Ketiga, Bagaimana konsepsi cyber notary dalam UUJN? Dalam UUJN paradigma mengenai cyber notary ini tercantum dalam penjelasan Pasal 15 ayat (3) UUJN yang menyebutkan: yang dimaksud dengan "kewenangan lain yang diatur dalam peraturan perundang-undangan", antara lain kewenangan mensertifikasi transaksi yang dilakukan secara elektronik (cyber notary), membuat akta ikrar wakaf, dan hipotek pesawat terbang. ${ }^{29}$ Makna dari kewenangan lain yang diatur dalam peraturan perundangundangan juga menimbulkan pertanyaan lebih lanjut seperti kewenangan seperti apa? Kewenangan dalam hal pembuatan akta atau non-akta? Apabila kewenangan tersebut kewenangan akta maka apakah akta tersebut sifatnya autentik atau tidak? Untuk mengetahui hal tersebut kita harus membahas 2 hal yaitu: kedudukan Pasal 15 ayat (3) UUJN terhadap Pasal 15 ayat (1) UUJN dan ayat (2) UUJN; dan penjelasan dari Pasal 15 ayat (3) UUJN itu sendiri.

Penjelasan Pertama, Pasal 15 termasuk dalam bab kewenangan notaris yang terdiri dari 3 ayat. Pasal 15 ayat (1) UUJN mencerminkan tugas pokok dari seorang notaris yang membuat akta autentik dalam hal: diharuskan oleh peraturan perundangundangan dan/atau permintaan oleh pihak yang berkepentingan. ${ }^{30}$ Pasal 15 ayat (2) UUJN dijelaskan sebagai kewenangan lain selain dari Pasal 15 ayat (1) UUJN. ${ }^{31}$ Artinya Pasal 15 ayat (2) UUJN dapat diartikan sebagai kewenangan yang tidak berkaitan dengan pembuatan akta dan kalau merujuk ketentuan Pasal 15 ayat (2) UUJN sebagian besar kewenangankewenangan tersebut tidak berkaitan dengan pembuatan akta kecuali dalam hal Pasal 15 ayat (2) huruf $\mathrm{f}^{32}$ dan $\mathrm{g}^{33}$.

Menurut penulis, apabila ketentuan terkait akta risalah lelang dan akta yang terkait dengan pertanahan dimasukkan dalam Pasal 15 ayat (2) UUJN maka dapat muncul penafsiran ganda, yaitu satu sisi masuk

Pasal 41 Undang-Undang Nomor 2 Tahun 2014 tentang Perubahan atas Undang-Undang Nomor 30 Tahun 2004 Tentang Jabatan Notaris.

28 Pasal 44 ayat (5) Undang-Undang Nomor 2 Tahun 2014 tentang Perubahan atas Undang-Undang Nomor 30 Tahun 2004 tentang Jabatan Notaris.

29 Penjelasan Pasal 15 ayat (3) Undang-Undang Nomor 2 Tahun 2014 tentang Perubahan atas Undang-Undang Nomor 30 Tahun 2004 tentang Jabatan Notaris.

30 Pasal 15 ayat (1) Undang-Undang Nomor 2 Tahun 2014 tentang Perubahan atas Undang-Undang Nomor 30 Tahun 2004 tentang Jabatan Notaris.

31 Pasal 15 ayat (2) Undang-Undang Nomor 2 Tahun 2014 tentang Perubahan atas Undang-Undang Nomor 30 Tahun 2004 tentang Jabatan Notaris.

32 Pasal 15 ayat (2) huruf f: Notaris berwenang membuat akta yang berkaitan dengan pertanahan.

33 Pasal 15 ayat (2) huruf g: Notaris berwenang membuat akta risalah lelang. 
dalam kualifikasi akta autentik sebagaimana Pasal 15 ayat (1) UUJN karena diharuskan oleh peraturan perundang-undangan dan/ atau permintaan pihak yang berkepentingan untuk dinyatakan dalam akta autentik, tapi disisi lain dapat juga masuk dalam kualifikasi bukan akta autentik, karena konstruksi dari Pasal 15 ayat (2) UUJN dimaksudkan sebagai kewenangan notaris selain pembuatan akta autentik, terbukti dengan adanya frase:"selain kewenangan yang dimaksud dalam Pasal 15 ayat ayat (1) notaris berwenang pula:.."

Selanjutnya, Pasal 15 ayat (3) menyebutkan bahwa selain kewenangan yang diatur dalam Pasal 15 ayat (1) dan ayat (2) notaris mempunyai kewenangan lain yang diatur dalam peraturan perundang-undangan. ${ }^{34}$ Mutatis mutandis ini juga menimbulkan tafsiran ganda apakah masuk kualifikasi kewenangan pembuatan akta autentik atau tidak. Perbedaan dengan Pasal 15 ayat (2) UUJN dan Pasal 15 ayat (3) UUJN ialah, Pasal 15 ayat (3) UUJN kewenangannya tidak disebutkan secara spesifik dan diatur di luar UUJN sedangkan Pasal 15 ayat (2) UUJN kewenangannya disebutkan secara spesifik di dalam UUJN.

Penjelasan Kedua, satu-satunya terdapat frasa cyber notary adalah dalam Penjelasan Pasal 15 ayat (3) yang menyatakan: "kewenangan lain yang diatur dalam peraturan perundang-undangan", antara lain, kewenangan mensertifikasi transaksi yang dilakukan secara elektronik (cyber notary), membuat akta ikrar wakaf, dan hipotek pesawat terbang. Dalam ilmu peraturan perundang-undangan penjelasan mempunyai 4 fungsi yaitu: ${ }^{35}$

a. Menjabarkan definisi/pengertian dan maksud dari suatu norma hukum;

b. Penjelasan dimaksudkan untuk memperjelas aturan-aturan yang masih kabur; atau mengandung ketidakjelasan sehingga aturan tersebut konsisten dengan tujuannya dibuat;

c. Menyediakan tambahan uraian pendukung terhadap tujuan utama dari undangundang agar keberadaannya semakin bermakna dan semakin berguna;

d. Membantu hakim dalam menafsirkan suatu peraturan.

UU No. 12 Tahun 2011 tentang Pembentukan Peraturan Perundang-Undangan menyebutkan Penjelasan mempunyai fungsi utama sebagai berikut: ${ }^{36}$

a. Penjelasan sebagai tafsir resmi dari pembentuk peraturan perundangundangan;

b. Penjelasan berfungsi untuk memperjelas norma dalam batang tubuh peraturan perundang-undangan;

c. Penjelasan tidak dapat digunakan membuat dasar hukum untuk membuat peraturan lebih lanjut dan tidak boleh mencantumkan rumusan yang berisi norma;

d. Penjelasan tidak menggunakan rumusan yang terselubung yang isinya mengubah secara terselubung ketentuan norma;

\footnotetext{
34 Pasal 15 ayat (3) Undang-Undang Nomor 2 Tahun 2014 tentang Perubahan atas Undang-Undang Nomor 30 Tahun 2004 tentang Jabatan Notaris.

35 Jimly Asshiddiqie, Perihal Undang-Undang (Depok: Rajawali Pers, 2017), hlm. 134.

36 Lampiran II Undang-Undang Nomor 12 Tahun 2011 tentang Pembentukan Peraturan Perundang-Undangan.
} 
Dari uraian di atas maka konsep cyber notary dimungkinkan untuk diatur lebih lanjut dalam peraturan lain di luar UUJN namun pertanyaannya adalah apakah ketika diatur di luar UUJN dapat menjadikan akta yang berbasis cyber notary ini dapat disebut akta autentik? Arti dari mensertifikasi transaksi yang dilakukan secara elektronik sebagaimana tercantum dalam penjelasan Pasal 15 ayat (3) tersebut belum terlalu jelas seperti apa konsep pengaturannya.

Merujuk dalam Peraturan Pemerintah Nomor 71 Tahun 2019 tentang Penyelenggaran Sistem dan Transaksi Elektronik maka arti dari sertifikat elektronik adalah: Sertifikat yang bersifat elektronik yang memuat tanda tangan elektronik dan identitas yang menunjukkan status subjek hukum para pihak dalam transaksi elektronik yang dikeluarkan oleh penyelenggara sertifikasi elektronik. ${ }^{37}$ Penyelenggara Sertifikasi Elektronik adalah badan hukum yang berfungsi sebagai pihak yang layak dipercaya, yang memberikan dan mengaudit Sertifikat Elektronik. ${ }^{38}$ Berdasarkan pengertian tersebut maka dapat disimpulkan bahwa yang dimaksud dengan kewenangan mensertifikasi transaksi yang dilakukan secara elektronik dapat diartikan sebagai Notaris sebagai lembaga yang diberikan kewenangan/ kepercayaan untuk mengaudit/memverifikasi tanda tangan elektronik dan identitas subyek hukum (trusted third party) atas suatu transaksi elektronik.
Berdasarkan penjelasan di atas maka Pasal 15 ayat (3) UUJN dapat dimaknai sebagai notaris dapat diberikan kewenangan mensertifikasi sertifikat elektronik, namun perlu pengaturan lebih lanjut tentang kewenangan sertifikasi elektronik tersebut dan harus ditegaskan apakah kewenangan tersebut masuk dalam kualifikasi Pasal 15 ayat (1) UUJN (akta autentik) atau tidak.

\section{Konsep pengaturan cyber notary dalam mendukung kemudahan berusaha di Indonesia}

Kemudahan berusaha atau ease of doing business (EODB) adalah sebuah konsep yang dicetuskan oleh Bank Dunia (world bank) untuk mengukur regulasi-regulasi yang berkaitan dengan dunia usaha dan penegakan hukum yang terkait dengan usaha. ${ }^{39}$ Sejak tahun 2002 dicetuskan hingga sekarang (2020) sudah ada kurang lebih 190 negara yang telah disurvei oleh Bank Dunia lewat indeks EODB. Tujuan dari doing business yang digagas oleh Bank Dunia adalah untuk mendong agar regulasiregulasi yang ada di suatu negara dapat lebih efisien, lebih transparan dan mudah diimplementasikan sehingga bisnis mudah untuk berkembang. ${ }^{40}$ Terutama bagi investor sebelum menginvestasikan modalnya ke suatu negara pasti akan mencari referensi tentang kondisi perekonomian negara tersebut. Informasi tersebut salah satunya didapatkan dari laporan doing business.

37 Pasal 1 angka 20 Peraturan Pemerintah Nomor 71 Tahun 2019 tentang Penyelenggaraan Sistem dan Transaksi Elektronik.

38 Pasal 1 angka 21 Peraturan Pemerintah Nomor 71 Tahun 2019 tentang Penyelenggaraan Sistem dan Transaksi Elektronik.

39 World Bank Group, "Economy Profile Indonesia: Doing Business 2020", World Bank, https://www.doingbusiness. org/content/dam/doingBusiness/country/i/indonesia/IDN.pdf. (diakses 5 Maret 2020).

40 World Bank Group, "Doing Business 2020: Comparing Business Regulation in 190 Economies", World Bank, http://documents.worldbank.org/curated/en/688761571934946384/pdf/Doing-Business-2020-ComparingBusiness-Regulation-in-190-Economies.pdf. (diakses 9 April 2020). 
Ada 4 (empat) alasan mengapa notaris wajib mendukung peningkatan kemudahan berusaha (EODB) ini di Indonesia. Alasan Pertama, Hal ini merupakan kebijakan dari pemerintah yang menghendaki agar Indonesia masuk dalam kategori negara ramah investasi. Negara dengan kemudahan berusaha yang baik akan mudah mendatangkan Investasi Asing Langsung. ${ }^{41}$ Oleh karena itu, Presiden Jokowi terus mendorong agar Indonesia dapat mendapatkan peringkat yang lebih baik dalam indeks doing business. ${ }^{42}$ Hasil penelitian juga menunjukkan ada korelasi positif dan signifikan antara indeks kemudahan berbisnis dengan kenaikan produk domestik bruto (PDB) di negara-negara ASEAN. ${ }^{43}$

Dikeluarkannya Peraturan Presiden Nomor 91 Tahun2017tentang Percepatan Pelaksanaan Berusaha tentu menjadi bukti keseriusan pemerintah dalam meningkatkan indeks kemudahan berusaha di Indonesia. Presiden Jokowi sendiri menyampaikan bahwa notaris harus ikut berperan dalam meningkatkan indeks kemudahan berusaha di Indonesia, salah satu caranya adalah menghilangkan tatap muka dalam penandatanganan suatu akta. ${ }^{44}$ Tatap muka dianggap oleh pemerintah sebagai penghalang untuk meningkatkan indeks kemudahan berusaha.
Alasan Kedua, Notaris selaku pejabat umum mempunyai 2 fungsi: Fungsi Pertama, sebagai pejabat yang menjalankan tugas negara dalam bidang privat. Fungsi Kedua, melayani masyarakat yang ingin membuat akta autentik. 2 fungsi tersebut tercantum di dalam konsideran dan penjelasan UUJN yang menyatakan konsepsi Indonesia sebagai negara hukum maka negara menjamin prinsipprinsip negara hukum dapat dijalankan dengan baik, seperti: menjamin kepastian, ketertiban dan perlindungan hukum. Kepastian, ketertiban, dan perlindungan hukum menuntut antara lain adanya alat bukti autentik. ${ }^{45}$ Fungsi tersebut menjadi penting dalam hal memenuhi kebutuhan dunia usaha yang membutuhkan kepastian hukum dalam setiap kegiatan bisnisnya.

Alasan Ketiga, Profesi notaris sangat erat kaitannya dengan dunia usaha, setidaknya ini ditujukan dari mekanisme penentuan kebutuhan (formasi) notaris di suatu daerah didasarkan kepada: ${ }^{46}$

a. Kegiatan dunia usaha;

b. Jumlah penduduk;

c. Rata-rata jumlah akta yang dibuat oleh notaris dalam setiap bulan.

Adanya pengaruh dunia bisnis terhadap tersedianya jumlah formasi notaris

41 Ni Luh Putu Dianawati \& Ni Putu Wiwin Setyari, "Pengaruh Kemudahan Berbisnis Terhadap Investasi Asing Langsung: Studi Kasus pada Negara Berkembang ASEAN", Vol. 7, No. 10 (2018), hlm. 2249-2277.

42 Investor Daily, "Jokowi Instruksikan Kepala BKPM Tingkatkan Akselerasi EODB", ,https://investor.id/business/ jokowi-instruksikan-kepala-bkpm-tingkatkan-akselerasi-eodb (diakses 24 Maret 2020).

43 Daniel Theodoris; Ni Putu Wiwin Setyari; Luh Putu Aswitari,"Pengaruh Indeks Kemudahan Berbisnis, Foreign Direct Investment, dan Populasi Penduduk Terhadap Perekonomian ASEAN", Vol. 6. No. 12 (2017), hlm. 23222351.

44 IHukum Online, "Buka Kongres Internasional Notaris, Ini Pesan Presiden Jokowi", https://www.hukumonline. com/berita/baca/lt5ddfb3c3ea922/buka-kongres-internasional-notaris--ini-pesan-presiden-jokowi/ (diakses 3 April 2020).

45 Konsiderans Menimbang huruf b Undang-Undang Nomor 30 Tahun 2004 tentang Jabatan Notaris.

46 Pasal 22 Undang-Undang Nomor 2 Tahun 2014 tentang Perubahan atas Undang-Undang Nomor 30 Tahun 2004 tentang Jabatan Notaris. 
membuktikan bahwa adanya hubungan erat antara jabatan notaris dan dunia usaha.

Alasan Keempat, Beberapa aspek yang dinilai oleh indeks EODB juga ada peran notaris di dalamnya. Aspek yang dinilai dalam EODB antara lain: (a) memulai usaha (starting business), (b) mengurus izin pembangunan (dealing with construction permits), (c) instalasi listrik (getting electricity), (d) mendaftarkan tanah (registering property), (e) memperoleh kredit/pinjaman (getting credit), (f) perlindungan terhadap investor minoritas (protecting minority investor), (g) perdagangan lintas batas (trading across borders), (h) membayar pajak (paying taxes), (i) penegakan hukum kontrak (enforcing contracts), (j) penyelesaian kepailitan (resolving insolvency), (k) mempekerjakan karyawan (employing workers). ${ }^{47}$

Bagan berikut ini merupakan aspek apa saja yang dinilai dari suatu indikator yang telah ditentukan: ${ }^{48}$
Starting Business

Dealing with construction permits

Getting electricity

Registering property

Getting credit

Protecting minority investors

Paying taxes

Trading across borders

Enforcing contracts

Resolving insolvency

Employing workers
Procedures, time, cost and paid-in minimum capital to start a limited liability company

Procedures, time and cost to complete all formalities to build a warehouse and the quality control and safety mechanisms in the construction permitting system

Procedures, time and cost to get connected to the electrical grid, and the reliability of the electricity supply and the transparency of tariffs

Procedures, time and cost to transfer a property and the quality of the land administration system

Movable collateral laws and credit information systems

Minority shareholders' rights in related-party transactions and in corporate governance

Payments, time, total tax and contribution rate for a firm to comply with all tax regulations as well as postfiling processes

Time and cost to export the product of comparative advantage and import auto parts

Time and cost to resolve a commercial dispute and the quality of judicial processes

Time, cost, outcome and recovery rate for a commercial insolvency and the strength of the legal framework for insolvency

Flexibility in employment regulation and redundancy cost

Data diambil dari laporan Doing Business

47 World Bank Group, "Economy Profile Indonesia: Doing Business 2020", https://www.doingbusiness.org/ content/dam/doingBusiness/country/i/indonesia/IDN.pdf. (diakses 5 Maret 2020).

$48 \quad$ Ibid. 
Peran notaris dari indikator tersebut setidaknya dalam hal memulai usaha (starting business). Misalnya dalam proses pendirian perusahaan (Perseroan Terbatas) dinilai dari indikator proses pendirian perusahaan sampai dalam tahap perusahaan dapat beroperasi. Dari bagan tersebut kita dapat mengetahui bahwa aspek prosedur (procedures), waktu (time), biaya (cost) dan modal dasar minimal pendirian PT (paid-in minimum capital to start a limited liability company) dinilai sebagai faktor yang dapat mempengaruhi kemudahan berusaha. Konsep cyber notary adalah yang terkait dengan efisiensi waktu. Oleh karena itu, pembahasan pola penerapan cyber notary ditujukan kepada aspek prosedur (procedures) dan waktu (time), sementara untuk biaya (cost) dan modal dasar minimal tergantung dari peraturan perundang-undangan yang lain.

Laporan Doing Business menyebutkan ada 11 tahapan prosedur yang harus dilalui ketika memulai usaha (starting business) atau membuat perusahaan, antara lain: ${ }^{49}$

\begin{tabular}{|c|c|c|}
\hline No & Procedures & Time to complete \\
\hline 1 & $\begin{array}{l}\text { Pay fee for obtaining clearance of company } \\
\text { name, }\end{array}$ & $\begin{array}{l}\text { Less than one day (online } \\
\text { procedure) }\end{array}$ \\
\hline 2 & $\begin{array}{l}\text { Obtain clearance for the company's name at the } \\
\text { Ministry of Law and Human Rights }\end{array}$ & $\begin{array}{l}\text { Less than one day (online } \\
\text { procedure) }\end{array}$ \\
\hline 3 & $\begin{array}{l}\text { Pay the non-tax state revenue (PNBP) fees for } \\
\text { legal services }\end{array}$ & $\begin{array}{l}\text { Less than one day (online } \\
\text { procedure) }\end{array}$ \\
\hline 4 & $\begin{array}{l}\text { Arrange for a notary to obtain the standard form } \\
\text { of the company deed and notarize company } \\
\text { documents }\end{array}$ & $1 d a y$ \\
\hline 5 & Make a company seal & 1 day \\
\hline 6 & $\begin{array}{l}\text { Apply to the Ministry of Law and Human Rights } \\
\text { for approval of the deed of establishment }\end{array}$ & $\begin{array}{l}\text { Less than one day (online } \\
\text { procedure) }\end{array}$ \\
\hline 7 & Apply for the Certificate of Company Domicile & $2 d a y$ \\
\hline 8 & Apply for the single business number (NIB) & 1 day \\
\hline 9 & Register with the Ministry of Manpower & 1 day \\
\hline 10 & $\begin{array}{l}\text { Apply for the Workers Social Security Program } \\
\text { (BPJS Ketenagakerjaan) and for the Healthcare } \\
\text { Insurance Program (BPJS Kesehatan) }\end{array}$ & $1 d a y$ \\
\hline 11 & $\begin{array}{l}\text { Obtain a taxpayer registration number (NPWP) } \\
\text { and a VAT collector number (NPPKP) }\end{array}$ & $\begin{array}{l}1 \text { day (simultaneous with } \\
\text { previous procedure) }\end{array}$ \\
\hline
\end{tabular}

49 Ibid. 
Dari ketentuan di atas yang menjadi kewenangan notaris berdasarkan UUJN hanyalah poin 4 yaitu terkait pembuatan akta. Pada praktiknya pembuatan akta perseroan terbatas (PT), ketentuan nomor 1, 2, dan 3 biasanya dilaksanakan juga oleh notaris. Hal tersebut juga dicatat oleh laporan indeks kemudahan berusaha bahwa poin 1,2,3 dan 4 dilaksanakan oleh notaris. ${ }^{50}$ Untuk poin 6 (mendapatkan pengesahan dari Menteri Hukum dan Hak Asasi Manusia) juga dilakukan oleh notaris setelah menandatangani akta pendirian PT. Tanpa adanya Surat Keputusan (SK) dari Menteri Hukum dan Hak Asasi Manusia suatu akta pendirian PT belum sah secara hukum. Beberapa poin lainnya yang disebutkan di atas juga sering diminta oleh klien untuk dikerjakan oleh notaris sekalian, seperti mengurus Surat Keterangan Domisili (certificate of company domicile). Biasanya para pihak ingin menerima suatu akta PT langsung jadi saja, karena tidak punya waktu untuk mengurus prosedur tersebut sendiri.

EODB menyatakan bahwa suatu prosedur dapat dikualifikasikan sebagai "less than one day" ketika dilakukan secara online (online procedure). ${ }^{51}$ Oleh karena itu, salah satu upaya dalam menaikkan indeks kemudahan berusaha di Indonesia adalah membenahi aspek prosedur dan waktu agar lebih efisien. Cara yang dapat digunakan adalah menjadikan akta notaris dalam pembuatan PT menjadi online agar dapat memenuhi kriteria less than one day (online procedure). Disinilah peran penting diimplementasikannya konsep cyber notary ke dalam Pasal 15 ayat (1) UUJN atau dalam pembuatan akta autentik. Jadi tidak hanya sebatas melakukan sertifikasi transaksi yang dilakukan secara elektronik. Perubahan dari offline ke online tentu akan berdampak pada penilaian indeks kemudahan berusaha.

Konsep perubahan offline ke online (cyber notary) tersebut harus menjawab 3 hal ini, yaitu: (1) perubahan kewenangan notaris seperti apa yang dapat mendukung kemudahan berusaha di Indonesia; (2) apakah perubahan kewenangan tersebut tidak mendegradasi makna akta autentik; (3) apakah aspek keamanan akta yang dibuat secara elektronik dapat terjamin. Pertama, kita harus mencermati kewenangan notaris dalam membuat akta berdasarkan UUJN. Pada dasarnya pekerjaan notaris dibagi dalam 3 tahap: (a) pra-pembuatan akta; (b) pembuatan akta; dan (c) pasca-pembuatan akta. Tahapan pra-pembuatan akta disebut juga tahapan menganalisis dokumen hukumnya, seperti meneliti subyek dan obyek hukumnya, dan kelengkapan dokumen-dokumen yang dibutuhkan dalam proses pembuatan akta. Tahapan ini biasanya membutuhkan pengalaman dan analisis hukum yang dimiliki seorang notaris.

Tahapan pembuatan akta, dapat disebut saat proses tanda tangan akta. Peran notaris disini memastikan bahwa ketentuan pembuatan akta harus dilaksanakan sesuai prosedur UUJN seperti: (a) wajib membacakan akta dihadapan penghadap dan saksi; ${ }^{52}$ dan (b) para pihak melaksanakan tanda tangan

\footnotetext{
Ibid.

51 Ibid.

52 Pasal 16 ayat (1) huruf m Undang-Undang Nomor 2 Tahun 2014 tentang Perubahan atas Undang-Undang Nomor 30 Tahun 2004 tentang Jabatan Notaris.
} 
dihadapan notaris ${ }^{53} .2$ (dua) kewenangan inilah yang menjadi batu sandungan dalam meningkatkan indeks kemudahan berusaha di Indonesia. Sementara kewenangan yang lain seperti ketentuan mengenai bahasa asing dalam akta, penambahan atau pencoretan dalam akta dan sebagainya sifatnya hanya insidental. Selanjutnya kewenangan pascapembuatan akta seperti menyimpan minuta akta yang sudah ditandatangani untuk menjadi bagian dari protokol notaris.

Perlu diketahui bahwa indikator doing business adalah mengukur kemudahan seseorang dalam membuat perusahaan. Salah satu hal yang dinilai sebagai kemudahan berusaha oleh Bank Dunia adalah ketika prosedur itu dapat dijalankan secara online yang dapat merubah prosedur dari one day mejadi less than one day. Tahapan yang berdampak langsung kepada aspek kemudahan berusaha adalah tahapan pembuatan akta, yaitu: pembacaan akta dihadapan klien dan tanda tangan klien harus di hadapan notaris. Oleh karena itu, Pasal 15 ayat (1) huruf m UUJN yang harus dirubah ke metode online. Perubahannya akan mengakibatkan ketika seseorang ingin membuat akta perusahan, tidak perlu bertemu oleh notaris saat penandatanganan akta, cukup melalui teknologi yang tersedia misalnya: video conference dalam pembacaan aktanya dan digital signature untuk tanda tangannya.

Kedua, apakah perubahan metode tersebut tidak akan mendegradasi akta autentik. Tentu anggapan tersebut muncul karena pekerjaan notaris identik dengan tinta dan kertas (metode konvensional). Bahkan ada asas yang menyatakan notaris harus bekerja secara tradisional atau asas Tabellionis Officium Fideliter Exercebo. ${ }^{54}$ Namun kalau kita merujuk pada definisi akta autentik, yaitu: (a) dibuat oleh pejabat yang berwenang; (b) dibuat sesuai undang-undang; (c) pejabat tersebut berwenang membuat ditempat kedudukannya, maka perubahan dari metode offline ke online tidak akan mendegradasi makna akta autentik asalkan diatur di dalam UUJN.

Ketiga, apakah aspek keamanan yang dibuat secara elektronik terjamin? Aspek autentik dalam hukum selalu dikaitkan dengan makna mempunyai pembuktian yang sempurna. Arti pembuktian yang sempurna adalah bahwa hakim tidak perlu mempertanyakan kebenaran yang termaktub dalam akta selama tidak dibuktikan sebaliknya dan pihak yang menyangkal akta tersebutlah yang wajib untuk membuktikan. Tujuan tersebut pada dasarnya terkait dengan kepercayaan dan keamanan akta autentik. Prosedur pembuatan akta autentik memang dibuat sedemikian rupa supaya dapat menjamin keamanan/kepercayaan seseorang terhadap akta tersebut yang hal ini berbeda dengan prosedur pembuatan akta di bawah tangan yang prosedur pembuatannya bebas tidak ditentukan oleh peraturan perundangundangan.

Berkaitan dengan aspek keamanan akta maka dapat kita balik pertanyaan tersebut menjadi: apakah prosedur pembuatan akta autentik sekarang (tradisional/konvensional) dapat menjamin keamanan? Tidak ada jaminan

53 Pasal 16 ayat (1) huruf m Undang-Undang Nomor 2 Tahun 2014 tentang Perubahan atas Undang-Undang Nomor 30 Tahun 2004 tentang Jabatan Notaris. 
ketentuan dengan metode konvensional akan lebih baik daripada penggunaan teknologi modern. Menurut pendapat penulis prosedur penandatanganan dengan cara elektronik justru lebih aman daripada metode konvensional. Sebagian ahli juga berpendapat bahwa pengaturan cyber notary di negara berkembang dapat meningkatkan tingkat keamanan (improving the level of security). ${ }^{54}$ Dengan keluarnya ketentuan yang mengatur tentang tata cara penggunaan tanda tangan elektronik tentu lebih terjamin dari aspek yuridis maupun aspek keamanannya.

Dalam Pasal 60 Peraturan Pemerintah Nomor 71 Tahun 2019 tentang Penyelenggaraan Sistem dan Transaksi Elektronik disebutkan bahwa tanda tangan elektronik mengenal yang namanya tanda tangan elektronik tersertifikasi dan tanda tangan elektronik tidak tersertifikasi. Tanda tangan elektronik tersertifikasi adalah tanda tangan yang harus memenuhi kriteria sebagai berikut:

a. memenuhi keabsahan kekuatan hukum dan akibat hukum tanda tangan elektronik sebagaimana dimaksud dalam Pasal 59 ayat (3) PP a quo;

b. menggunakan sertifikat elektronik yang dibuat oleh jasa penyelenggara sertifikasi elektronik Indonesia;

c. dibuat dengan menggunakan perangkat pembuat tanda tangan Elektronik tersertifikasi.

Dari ketentuan tersebut tentunya notaris dapat menggunakan instrumen tanda tangan elektronik tersertifikasi untuk lebih menjamin keamanan dari suatu akta.

\section{Penutup}

Berdasarkan analisis dan uraian di atas, dapat disimpulkan sebagai berikut: Pertama, Konsep cyber notary yang ada sekarang dimaknai sebatas pada sertifikasi transaksi secara elektronik. UUJN membuka peluang agar konsep cyber notary diatur lebih lanjut dalam peraturan perundang-undangan, akan tetapi harus ditegaskan apakah kewenangan cyber notary tersebut termasuk kewenangan pembuatan akta autentik atau tidak.

Kedua, Untuk menuju konsep cyber notary yang dapat meningkatkan indeks kemudahan berusaha di Indonesia ialah merubah Pasal 15 ayat (1) UUJN dan menambahkan kewenangan agar pembacaan akta dan tanda tangan diperbolehkan tanpa tatap muka dengan menggunakan teknologiteknologi yang berkembang saat ini, seperti video conference dan digital signature. Dengan cara tersebut (secara online) maka prosedur pembuatan akta dapat dipotong, sehingga prosesnya kurang dari 1 (satu) hari. Terlebih dengan kondisi yang melanda saat ini, adanya wabah Covid-19 menjadikan pengaturan cyber notary harus segera diimplementasikan.

\section{Daftar Pustaka}

\section{Buku}

Asshiddiqie, Jimly, Perihal Undang-Undang, (Depok: Rajawali Pers, 2017).

Becker, S. Ann, Electronic Commerce: Concepts, Methodologies, Tools, and Applications, (Hershey: IGI Global, 2007).

Marzuki, Peter Mahmud, Penelitian Hukum (Jakarta: Prenadamedia group, 2019).

54 S. Ann Becker, Electronic Commerce: Concepts, Methodologies, Tools, and Applications (Hershey: IGI Global, 2007), hlm. 59. 
Mertokusumo, Sudikno, Mengenal Hukum: Suatu Pengantar (Yogyakarta: Cahaya Atma Pustaka, 2010).

Murni, Retno. et al., Pelaksanaan Kegiatan Pengabdian Masyarakat: Diseminasi tentang Risalah RUPS PT Menuju Akta Otentik dari Prespektif Cyber Notary (Bali: Magister Kenotariatan Universitas Udayana, 2014).

Smith, Leslie G., The Role of Notary in Secure Electronic Commerce, Thesis, (Brisbane: Queensland University of Technology, 2006).

Soekanto, Soerjono, Pengantar Penelitian Hukum (Jakarta: UI-Press, 1986).

Sukarmi, Cyber Law: Kontrak Elektronik dalam Bayang-Bayang Pelaku Usaha, (Bandung: Pustaka Sutra, 2008).

\section{Makalah/Artikel/Prosiding/Hasil Penelitian}

Daniel Theodoris; Ni Putu Wiwin Setyari dan Luh Putu Aswitari, "Pengaruh Indeks Kemudahan Berbisnis, Foreign Direct Investment, dan Populasi Penduduk Terhadap Perekonomian ASEAN", Vol. 6, No. 12 (2017).

Dianawati, Luh Putu dan Setyari, Ni Putu Wiwin, "Pengaruh Kemudahan Berbisnis Terhadap Investasi Asing Langsung: Studi Kasus pada Negara Berkembang ASEAN", Vol. 7, No. 10 (2018).

Habib Adjie, "Konsep Notaris Mayantara Menghadapi Tantangan Persaingan Global", Jurnal Hukum Respublica, Vol. 16, No. 2 (2017).

Iryadi, Irfan, "Kedudukan Akta Otentik dalam Hubungannya dengan Hak Konstitusional Warga Negara", Jurnal Konstitusi, Vol. 15, No. 4 (2018).

Makarim, Edmon, "Modernisasi Hukum Notaris Masa Depan: Kajian Hukum Terhadap Kemungkinan Cyber Notary di Indonesia", Jurnal Hukum \& Pembangunan, Vol. 41, No. 3 (2011).

Putri, Debi Eka; Lie, Darwin; Efendi dan Inrawan, Ady, "Pengaruh Kualitas Pelayanan Jasa Terhadap Kepuasaan Pelanggan pada Kantor Notaris dan PPAT Rachmansyah Purba S.H., M.Kn. di Kota Pematangsiantar" Jurnal Sultanist, Vol. 2, No. 2 (2014).

Syamsir; Rahmi, Elita dan Yetniwati, "Prospek Cyber Notary Sebagai Media Penyimpanan Pendukung Menuju Profesionalisme Notaris", Recital Review, Vol. 1, No. 2 (2019).
Yetniwati; Rahmi, Elita dan Hartati, "Peran Notaris Dalam Pembuatan Kontrak Bisnis, Pengabdian Masyarakat Pada Fakultas Hukum Universitas Jambi", Jurnal Karya Abdi Masyarakat, Vol. 3, No. 2 (2019).

\section{Internet}

CNBC INDONESIA, "Jokowi Bidik Indonesia Indonesia Bisa Capai Peringkat 40 EODB", https://www.cnbcindonesia.com/ news/20200213142449-8-137644/jokowibidik-indonesia-bisa-capai-peringkat-40-eodb (diakses 05 Maret 2020).

Hukum Online, "Buka Kongres Internasional Notaris, Ini Pesan Presiden Jokowi", https://www. hukumonline.com/berita/ baca/lt5ddfb3c3ea922/buka-kongresinternasional-notaris--ini-pesan-presidenjokowi/ (diakses 3 April 2020)

Hukum Online, "Presiden Minta Pola Kerja Notaris Berubah, Begini Tanggapan INI", https://www.hukumonline.com/berita/ baca/It5de0fe8832c1b/presiden-minta-polakerja-notaris-berubah--begini-tanggapan-ini/ (diakses 05 Maret 2020).

Investor Daily, "Jokowi Instruksikan Kepala BKPM Tingkatkan Akselerasi EODB", , https://investor. id/business/jokowi-instruksikan-kepalabkpm-tingkatkan-akselerasi-eodb (diakses 24 Maret 2020).

Irma Devita, "Cyber Notary - Sebatas Gagasan Atau Masa Depan", https://irmadevita. com/2019/cyber-notary-sebatas-gagasanatau-masa-depan/ (diakses 05 Maret 2020).

Laurence Leff (editor), "Notaries and Electronic Notarization", https://www.oasis-open. org/committees/download.php/4541/ enotarization.pdf. (diakses 07 April 2020).

World Bank Group, "Economy Profile Indonesia: Doing Business 2020", https:// www.doingbusiness.org/content/dam/ doingBusiness/country/i/indonesia/IDN.pdf. diakses (5 Maret 2020).

World Bank. 2020. Doing Business 2020. Washington, DC: World Bank, http:// documents.worldbank.org/curated/ en/688761571934946384/pdf/DoingBusiness-2020-Comparing-BusinessRegulation-in-190-Economies.pdf. (diakses 9 April 2020). 


\section{Peraturan}

Indonesia, Kitab Undang-Undang Hukum Perdata, Staatsblad Tahun 1847 Nomor 23.

Indonesia, Undang-Undang Nomor 30 Tahun 2004 tentang Jabatan Notaris, Lembaran Negara Republik Indonesia Tahun 2004 Nomor 117.

Indonesia, Undang-Undang Nomor 11 Tahun 2008 tentang Informasi dan Transaksi Elektronik, Lembaran Negara Republik Indonesia Tahun 2008 Nomor 58.

Indonesia, Undang-Undang Nomor 12 Tahun 2011 tentang Pembentukan Peraturan Perundang-
Undangan, Lembaran Negara Republik Indonesia Tahun 2011 Nomor 82.

Indonesia, Undang-Undang Nomor 2 Tahun 2014 tentang Perubahan Atas Undang-Undang Nomor 30 Tahun 2004 tentang Jabatan Notaris, Lembaran Negara Republik Indonesia Tahun 2014 Nomor 3.

Indoneisa, Peraturan Pemerintah Nomor 71 Tahun 2019 tentang Penyelenggaraan Sistem dan Transaksi Elektronik, Lembaran Negara Republik Indonesia Tahun 2019 Nomor 185. 